\title{
Indirect electrochemical degradation of acetaminophen: process performance, pollutant transformation, and matrix effects evaluation
}

Degradación electroquímica indirecta de acetaminofén: desempeño del proceso UNIVERSIDAD DE ANTIOQUIA Efraím A. Serna-Galvis (iD 1,2, Juan Esteban Ramírez iD ${ }^{2}$, Ricardo E. Palma-Goyes iD ${ }^{3}$, Ricardo A.
Torres-Palma iD 2*
${ }^{1}$ Grupo de Investigaciones Biomédicas, Facultad de Ciencias de la Salud. Corporación Universitaria Remington
(Uniremington). Calle 51 \# $51-27$. C. P. 050010. Medellín, Colombia.
${ }^{2}$ Grupo de Investigación en Remediación Ambiental y Biocatálisis (GIRAB), Instituto de Química, Facultad de Ciencias
Exactas y Naturales. Universidad de Antioquia. Calle 70 \# $52-21$. C. P. 050010. Medellín, Colombia.
${ }^{3}$ Departamento de Química. Universidad del Valle. Calle 13 \# 100-00, C. P. 760032. Santiago de Cali, Colombia. 1803

\section{CITE THIS ARTICLE AS:}

E. A. Serna-Galvis, J. E. Ramírez, R. E. Palma-Goyes and R. A. Torres-Palma. "Indirect electrochemical degradation of acetaminophen: process performance, pollutant transformation, and matrix effects evaluation", Revista Facultad de Ingeniería Universidad de Antioquia, no. 106, pp. 113-123, Jan-Mar 2023. [Online]. Available: https:

//www.doi.org/10.17533/ udea. redin. 20211166

\section{ARTICLE INFO:}

Received: February 03, 2021 Accepted: November 06, 2021 Available online: November 06, 2021

\section{KEYWORDS:}

Electrochemistry; chlorination; pharmaceuticals; water treatment

Electroquímica; cloración; medicamentos; tratamiento de aguas
ABSTRACT: Acetaminophen (ACE), a highly consumed pharmaceutical, was degraded in aqueous matrices by reactive chlorine species (RCS) electrogenerated using $\mathrm{Ti} / \mathrm{IrO}_{2}$ electrodes. Although this pollutant has been extensively treated by electrochemical techniques, little information is known about its degradation in fresh urine by electrogenerated RCS, and the understanding of its transformations using analyses of atomic charge. In this work, these two topics were discussed. Initially, the effect of current (10-40 mA) and supporting electrolyte (considering typical ions present in surface water and urine $\left(\mathrm{Cl}^{-}\right.$and $\left.\left.\mathrm{SO}_{4}^{2-}\right)\right]$ on the electrochemical system was evaluated. Then, the kinetics and primary transformations products involved in the elimination of ACE were described. It was found that, in distilled water, the process at $40 \mathrm{~mA}$ in $\mathrm{NaCl}$ presence led to $100 \%$ of ACE degradation $110 \mathrm{~min}, 0.056 \mathrm{Ah}$ $L^{-1}$ ). Theoretical analyses of atomic charge for ACE indicated that the amide group is the most susceptible to attacks by RCS such as $\mathrm{HOCl}$. On the other hand, degradation of acetaminophen in synthetic fresh urine was slower $121 \%$ of degradation after 60 min of treatment) than in distilled water. This was attributed to the other substances in the urine matrix, which induce competition for the degrading RCS.

RESUMEN: El acetaminofén (ACE), un farmacéutico muy consumido en todo el mundo; fue degradado en matrices acuosas por oxidación con especies reactivas de cloro (ERC) electro-generadas usando electrodos de $\mathrm{Ti} / \mathrm{IrO}_{2}$. A pesar de que este contaminante ha sido tratado extensamente mediante técnicas electroquímicas, se tiene poca información sobre su degradación en orina por ERC electrogeneradas fresca, y sobre la comprensión de sus transformaciones usando análisis de carga atómica. En este trabajo se discutieron estos dos temas. Inicialmente, se evaluó el efecto de la corriente (10-40 mA) y electrolito soporte (considerando iones típicos del agua superficial y la orina $\left(\mathrm{Cl}^{-}\right.$y $\left.\left.\mathrm{SO}_{4}^{2-}\right)\right)$, sobre el sistema electroquímico. Luego se describieron la cinética de oxidación y transformaciones primarias de ACE. Se encontró que, en agua destilada, el proceso a $40 \mathrm{~mA}$ y en presencia de $\mathrm{NaCl}$ condujo al 100\% de degradación de ACE en 10 min de tratamiento (0.056 Ah $L^{-1}$ ). Los análisis teóricos de la carga atómica sobre ACE indicaron que el grupo amida es el más susceptible a los ataques de las ERC como el HOCl. Por otro lado, la degradación del acetaminofén en orina fresca sintética fue mucho más lenta $121 \%$ de remoción de 60 min de tratamientol que en agua destilada. Esto debido a que las otras sustancias en la matriz de la orina inducen una competencia por las ERC.

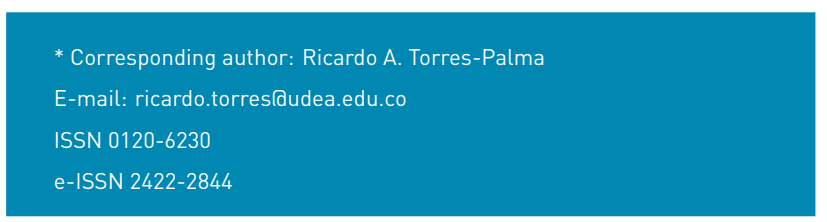

\section{Introduction}

Up to date, analgesics and anti-inflammatories are pharmaceuticals used worldwide to relieve pain and 
suppress inflammation [1]. Due to the high utilization and continuous excretion through urine, a large fraction of water pollution is associated with anti-inflammatory and analgesic products [2]. They are omnipresent in wastewaters [3]. Acetaminophen lalso named paracetamoll is one of the most consumed analgesics and anti-inflammatories. This analgesic is frequently detected in municipal wastewater treatment plants (MWTP) effluents $[4,5]$. Because of the inability of conventional processes in MWTP to eliminate pharmaceuticals such as acetaminophen (ACE), they end up in the natural water. In the environment, ACE and/or its corresponding metabolites can induce negative influence on aquatic organisms such as fishes, protozoa, and algae even at very low concentrations $[2,6,7]$. Thereby, technological developments for degrading ACE before its aquatic media input are required to diminish the negative impact of this analgesic on the environment.

Several oxidation processes, including the Fenton system [8], ozonation [9], ultrasound [10], and photocatalytic-oxidation [11], have been proposed for degrading ACE in water. Nevertheless, some inherent disadvantages le.g., acidic $\mathrm{pH}$ requirements, catalysts addition and recovery, metal complexation, high electric energetic demand, or long UV exposure time [8, 12, 13] limit the application of these methods. A promising alternative is the indirect oxidation by electrogenerated reactive chlorine species (RCS, $\mathrm{Cl}_{2}, \mathrm{E}^{\circ}$ : $1.36 \mathrm{~V} ; \mathrm{HOCl}, \mathrm{E}^{\circ}$ : $1.49 \mathrm{~V}$; and $O C l^{-}, \mathrm{E}^{\circ}: 0.89 \mathrm{~V}$ ), which can be used to treat micropollutants and persistent contaminants (such as analgesics) in aqueous matrices [14-21]. The RCS act as oxidizing agents, and they have lower potentials than other oxidants (hydroxyl radical or sulfate radical), which makes RCS more selective for the attack to organic pollutants $[14,15,17,22,23]$. The use of these species is gaining interest due to they are generated electrochemically from chloride ions present in situ in multiple aqueous matrices le.g., urine, where chloride ions can be exploited as natural reagents). RCS are mainly produced by the action of dimensionally stable anodes (DSA) such as $\mathrm{Ti} / \mathrm{RuO}$ or $\mathrm{Ti} / \mathrm{IrO}_{2}$. These classes of anodes have a large surface area, elevated catalytic activity to the RCS production, low corrosion, and electric energy consumption [24-27].

Previous studies have tested the indirect electrochemical oxidation of ACE $[28,29]$. However, the application of theoretical analysis of atomic charge la useful tool to study the reactivity of organic pollutants to the oxidizing species) and ACE degradation in a complex matrix such as urine (the main excretion route for this pharmaceutical) were not reported in these articles. Additionally, the above-mentioned works did not use DSA (which, up to date, are the best anodes for the generation of RCS) in the electrochemical processes. Therefore, this research deals with the elimination of ACE in distilled water and fresh urine by RCS produced on a $\mathrm{Ti} / \mathrm{IrO}_{2}$ anode (DSA). Firstly, the ability of the electrochemical system to generate RCS, under modifications of electrolyte-type and current intensity, was tested. Secondly, ACE elimination by indirect electrochemical oxidation was evaluated at favorable conditions of current and supporting electrolyte. Then, the regions on ACE susceptible to attacks of RCS were established through theoretical analyses of atomic charge, and the formation of the primary degradation products is discussed. Finally, the feasibility of the process, to degrade ACE in synthetic fresh urine was considered.

\section{Experimental Section}

\subsection{Reagents}

Acetonitrile (HPLC grade), ammonium chloride (99.0\%), ammonium heptamolybdate (99.9\%), potassium chloride $(99.5 \%)$, sodium acetate $(99.0 \%)$, sodium chloride $(99.0 \%)$, sodium hydroxide (99.0\%), sodium sulfate $(99.0 \%)$, and sulfuric acid (96\%) were purchased from Merck. Urea (99.5\%) was supplied by M\& B Laboratory Chemicals. Disodium hydrogen phosphate heptahydrate (98\%), magnesium chloride hexahydrate (99.0\%), calcium chloride dihydrate (98.0\%), and potassium iodide $(99.5 \%)$ were provided by PanReac. Formic acid (98.0\%) was obtained from Carlo-Erba. Acetaminophen (99.0\%) was provided by Laproff laboratories (Colombia). Synthetic fresh urine was prepared according to Amstutz et al. 2012 [30] (Table 1).

Table 1 Composition of synthetic fresh urine*

\begin{tabular}{lc}
\hline Substance & Concentration $\left(\mathbf{m o l}^{-1}\right)$ \\
\hline Acetate & 0.125 \\
Ammonium & 0.034 \\
Calcium & 0.005 \\
Chloride & 0.107 \\
Magnesium & 0.004 \\
Phosphate & 0.024 \\
Potassium & 0.056 \\
Sodium & 0.184 \\
Sulfate & 0.016 \\
Urea & 0.266 \\
pH & 6.1 \\
\hline
\end{tabular}

*Formulation taken from Amstutz et al. 2012 [30] 


\subsection{Reaction system}

Degradation of ACE was performed in an undivided cell, containing a $\mathrm{Ti} / \mathrm{IrO}_{2}\left(8 \mathrm{~cm}^{2}\right.$ of areal anode and a zirconium spiral $(10 \mathrm{~cm}$ in length) cathode. Samples of $120 \mathrm{~mL}$ were used in all cases, under constant stirring speed (150 rpm) using a magnetic stirrer. The experiments were carried out at least by duplicate. The samples to be treated contained $40 \mu \mathrm{mol} L^{-1}$ of ACE $\left(6.05 \mathrm{mg} \mathrm{L}^{-1}\right)$; this concentration was selected taking into account that the analgesics are mainly excreted through urine at $m g L^{-1}$ levels [31].

\subsection{Analyses}

The degradation of ACE was determined utilizing a UHPLC Thermo Scientific Dionex UltiMate 3000 instrument, equipped with an Acclaim ${ }^{\mathrm{TM}} 120$ RP-C18 column (5 $\mu \mathrm{m}$, $4.6 \times 150 \mathrm{~mm}$ ) and a diode array detector (at $243 \mathrm{~nm}$ ). A mixture of acetonitrile: formic acid $\left(10 \mathrm{mmol} L^{-1}\right)$ at $15: 85 \mathrm{v} / \mathrm{v}$ under a flow rate of $0.45 \mathrm{~mL} \mathrm{~min}^{-1}$ was the mobile phase, and $20 \mu \mathrm{L}$ of the sample were injected into the UHPLC apparatus. The RCS accumulation during the treatments was quantified by the iodometry method as reported by Yañez-Rios et al. 2020 [32]. In this method, $600 \mu \mathrm{L}$ of the sample reacted with $1350 \mu \mathrm{L}$ of $0.1 \mathrm{~mol} \mathrm{~L}^{-1}$ potassium iodide, and $50 \mu \mathrm{L}$ of $0.01 \mathrm{~mol} L^{-1}$ ammonium heptamolybdate. After 5 min of reaction, the absorbance at $350 \mathrm{~nm}$ was established using a UV5 Mettler-Toledo spectrophotometer.

Cyclic voltammetry tests were performed using an Autolab PGSTAT 30 apparatus, in a conventional three-electrode cell. The $\mathrm{Ti} / \mathrm{IrO}_{2}$ anode was used as a working electrode, $\mathrm{Ag} / \mathrm{AgCl}(3.0 \mathrm{M} \mathrm{KCl})$ as the reference electrode, and the zirconium spiral as the counter electrode. The measurements were conducted at a sweep rate of $50 \mathrm{mV}$ $s^{-1}$.

The theoretical analyses of atomic charge for ACE were performed using a free online atomic charge calculator. Empirical atomic charges that respond to changes in molecular conformation are calculated via an efficient implementation of the well-established electronegativity equalization method (EEM). The atomic charges in ACE (coordinates from wwPDB CCD entry TYL). The total molecular charge of zero was used. The EEM parameter set Ouy2009-elem covered the NPA charge definition at the B3LYP/6-31G* level of theory [33].

\section{Results and discussion}


was varied between 10 and $40 \mathrm{~mA}$, to avoid an excess of the parasitic oxygen evolution reaction (OER, Equation (9)) and limit the formation of toxic chlorine species (such as chlorate) and high electric consumption. Figure $1 \mathrm{~b}$ shows that the concentration of RCS after 10 min of electrolysis increases from 135 to $324 \mu \mathrm{mol} L^{-1}$ as $i$ grows up from 10 to $40 \mathrm{~mA}$. The increment in the current intensity favors the movement of the electrons, and consequently, the generation of RCS (Equations (1)-(4)). Nevertheless, an excessive augmentation of $i$ has disadvantages since side processes like OER (Equations (7)-(9)] or other parasitic reactions (as chlorate formation [37, 38]) may decrease the current efficiency and increase the electric energy consumption.

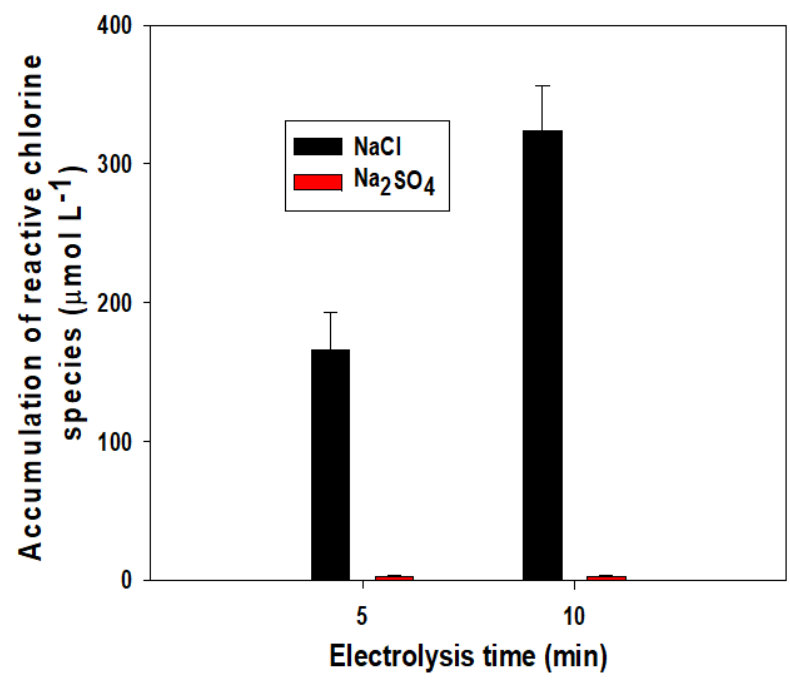

(a) Effect of electrolyte type on the electrochemical system (Experimental conditions: $0.05 \mathrm{~mol} L^{-1}$ of $\mathrm{NaCl}$ or $\mathrm{Na}_{2} \mathrm{SO}_{4}$, $\mathrm{pH}: 6.0$, and $i: 40 \mathrm{mAl}$

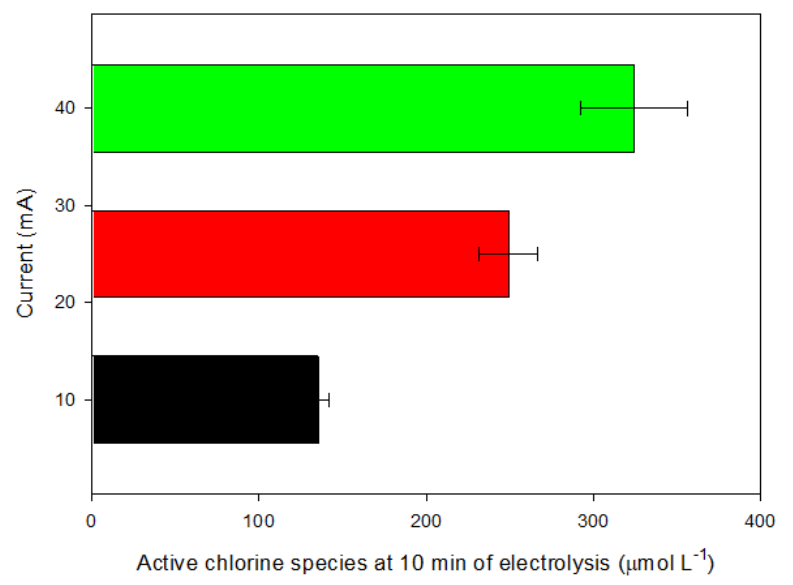

(b) Effect of current (Experimental conditions: $0.05 \mathrm{~mol} L^{-1}$ of $\mathrm{NaCl}, \mathrm{pH}:$ 6.0)

Figure 1 Generation of chlorine species
Based on the above results, we can indicate that for our electrochemical system, $\mathrm{NaCl}$ as the supporting electrolyte, and $40 \mathrm{~mA}$ of current intensity are suitable settings that favor the electrogeneration of the RCS. Therefore, these conditions were applied to the system for the treatment of the target analgesic.

\subsection{Degradation of ACE by the electrochemical system}

After evaluation of the electrolyte type and the current intensity effects, the treatment of ACE was assessed. Figure $2 a$ presents the evolution of ACE under the electrochemical oxidation system, in distilled water in the presence of $\mathrm{NaCl}$ or $\mathrm{Na}_{2} \mathrm{SO}_{4}$ (at $0.05 \mathrm{~mol} L^{-1}$ and $40 \mathrm{~mA}$ ). The process using $\mathrm{NaCl}$ as the supporting electrolyte led to the complete degradation of the target pollutant after $10 \mathrm{~min}$ of electrolysis lequivalent to an electric charge of $0.056 \mathrm{Ah} \mathrm{L}^{-1}$ ). Meanwhile, when $\mathrm{Na}_{2} \mathrm{SO}_{4}$ was used, only $10 \%$ of ACE was degraded after 10 min of treatment.

In addition to the ACE evolution, the accumulation of oxidizing species in both presence and absence of the pharmaceutical, for the system with $\mathrm{NaCl}$, was determined (Figure 2b). In the ACE presence, the concentration of the oxidant was $23 \%$ lower than in the pharmaceutical absence. This indicates an interaction of the acetaminophen with the electrogenerated RCS $[17,34]$. Moreover, the treatment of ACE using $\mathrm{Na}_{2} \mathrm{SO}_{4}$ as the supporting electrolyte (the system where RCS are not produced) indicates that the contribution of the direct degradation route through electrons transfer from the pollutant to the anode is low at short treatment times such as $10 \mathrm{~min}$.

To better clarify these aspects, cyclic voltammetry analyses were performed (Figure 2c). Cyclic voltammetry tests using the $\mathrm{Na}_{2} \mathrm{SO}_{4}$ electrolyte (red line) exhibit a small wave at $\sim 0.6 \mathrm{~V}$, which can be related to the oxidation of ACE on the anode surface, and the predominant peak at $\sim 1.5 \mathrm{~V}$ is the OER. On the other hand, when $\mathrm{NaCl}$ was used as an electrolyte (blue line), a wave around $0.7 \mathrm{~V}$ was recorded (this can also be associated with the direct oxidation of ACE on the anode surfacel. Furthermore, the peak at $\sim 1.5 \mathrm{~V}$ corresponds to the mix of OER and chlorine evolution reaction (both water and chloride oxidations occur at very close potentials, and as the water concentration is much higher than $\mathrm{Cl}^{-}$, the OER peak masks the chloride oxidation; thus only a big signal is observed, [24, 25]].

At the experimental $\mathrm{pH}$ (6.0), in the system with $\mathrm{NaCl}$ as the supporting electrolyte, $\mathrm{HOCl}$ is the predominant reactive chlorine species (Equations (5) and (6)). Then, this agent is the main responsible for ACE degradation in the 
electrochemical system, and at the current intensity used in this work (i.e., $40 \mathrm{~mA}$ ), the degradation through electron transfers from the pollutant to the anode occurs (Figures $2 \mathrm{a}$ and $2 \mathrm{c}$ ), but its contribution is low.

It is reported that the hypochlorous acid is a powerful oxidizing agent $\left(E^{\circ}=1.49 \mathrm{~V}\right.$ vs. $\left.\mathrm{SHE}\right)$ able to attack organic pollutants as ACE [23]. From Figure $2 b$, it can be noted that the half-life time of ACE is $\sim 3.5 \mathrm{~min}$, which is a very short time. This can be associated with the strong degrading action of the electrogenerated HOCl. Pinkston and Sedlak have studied the degradation of acetaminophen by direct chlorination, showing under such a system ACE has a half-life time of $5.2 \mathrm{~min}$ [39]. Similarly, Bredner and MacCrehan informed the treatment of ACE by chlorination, founding a half-life time of $7.2 \mathrm{~min}$ in pure water, and an effective degradation in wastewater [40]. Also, it is informed in the literature that as the amount of chlorine species in water is increased, the ACE degradation is higher [41]. The comparison of our results with literature evidenced the usefulness of electrogenerated RCS to fastly degrade ACE.

\subsection{Regions on ACE attacked by $\mathrm{HOCl}$, and possible primary degradation products}

As an initial approach to understanding the action of the electrogenerated RCS on ACE, theoretical calculations were done. Analyses to determine the regions on the pharmaceutical, susceptible to attacks by the RCS, were performed on the free online atomic charge calculator [33], and the results are presented in Table 2. A more negative value for the atomic charge means a higher electron density.

The theoretical analysis of atomic charge for ACE indicated that the amide group has the highest electron density lwhich suggests such moiety on the pharmaceutical is the most susceptible to attacks by electrophilic species such as $\mathrm{HOCl}$. Besides, oxygen in the hydroxyl and some carbons (C4, C5, C7, and C8) on the aromatic ring could also be attacked by the electrogenerated $\mathrm{HOCl}$. However, the amide group has a charge more negative than the phenyl moiety (Table 2). The amide group is more susceptible to oxidation than phenyl due to nitrogen is less electronegative than oxygen [42]. Additionally, the results of the atomic charge analysis for ACE were consistent with the reported reactivity of chlorine species such as hypochlorous acid, which attacks preferentially activated amides, phenols, and reduced moieties on the structure of organic contaminants [23].

In addition to the theoretical calculations, the chromatographic detection of some primary stable transformation products was done. Figure 3 contains the chromatogram for ACE after 7 min of electrolysis. It can be noted that the electrochemical process produced three primary degradation intermediates (named 4.9, 5.9, and 9.5). Two products appear at lower retention times $(4.9$ and $5.9 \mathrm{~min}$, respectively) than ACE (retention time: 6.3 min), while a third intermediate was more retained in the column than the parent pharmaceutical Iretention time: $9.5 \mathrm{~min})$. Considering the nature of the chromatographic method (i.e., reverse phase, see Section 2.3), we can indicate that the products having retention times of 4.9 and $5.9 \mathrm{~min}$ were more polar than ACE, whereas the product with a retention time of $9.5 \mathrm{~min}$ was less polar than acetaminophen.

Previous works about the chlorination of acetaminophen have reported that the degradation of ACE produces compounds such as 1,4-benzoquinone, $N$-acetyl- $p$-benzoquinone imine (NAPQI), and intermediaries from chlorination on the aromatic ring [39, 40, 43]. NAPQI and 1,4-benzoquinone are more hydrophilic than ACE las indicated by their Log P-values lower than for ACE, see Table 2); thus, the peaks at lower retention times than the parent pharmaceutical may correspond to these substances. Meanwhile, intermediaries coming from chlorination are less hydrophilic than ACE (Table 3); then, the peak at 9.5 min in Figure 3 may be a chlorinated product.

It can be remarked that NAPQI and1,4-benzoquinone come from the attack of chlorine species to the amide group on $A C E$, which was consistent with the highest electron-rich nature of this functional group las indicated by the atomic charge analysis, Table 2). NAPQI formation starts in the interaction of the amide on ACE with the electrogenerated $\mathrm{HOCl}$, for which a six members ring transition state may be proposed (Figure 4a). This transition state evolves to $\mathrm{N}$-chloramide and hydroxyl anion [45]. The released hydroxyl anion can react with the acid hydrogen on the phenyl group, promoting the formation of NAPQI, being the chloride ion a leaving group. The imine group on NAPQI undergoes hydrolysis $[40,46]$, releasing 1,4-benzoquinone and acetamide (Figure 4b).

Regarding chlorinated products, we can indicate that the aromatic ring on ACE is activated to interact with the electrogenerated $\mathrm{HOCl}$. Hence, chlorination of ACE through mechanisms of aromatic electrophilic substitution can occur (Figure 4c). The hydroxyl moiety is ortho and para directing for the substitution promoted by $\mathrm{HOCl}$ [23]. However, as the amide group already occupies the para position on ACE, the chlorinations occur on the ortho positions (which is according to the negative atomic charges on C5 and C7 of ACE, Table 2). Indeed, the chlorination in ortho positions has been also reported for the treatment of ACE by the UV/HOCl process [47], 


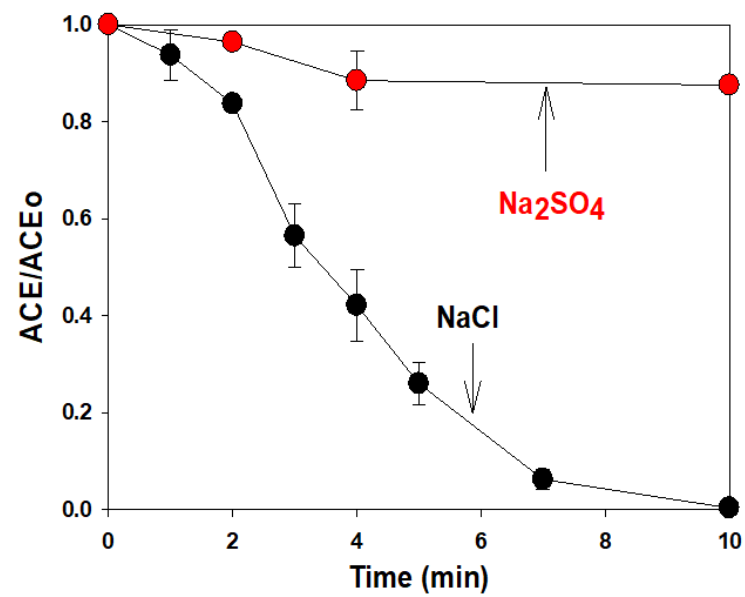

(a) ACE evolution using $\mathrm{NaCl}$ or $\mathrm{Na}_{2} \mathrm{SO}_{4}$ as supporting electrolyte (Experimental conditions: ACE: $40 \mu \mathrm{mol} L^{-1}$ $\mathrm{NaCl}: \mathrm{Na}_{2} \mathrm{SO}_{4}$ : $0.05 \mathrm{~mol} L^{-1}, i: 40 \mathrm{~mA}$, and $\left.\mathrm{pH}: 6.0\right)$

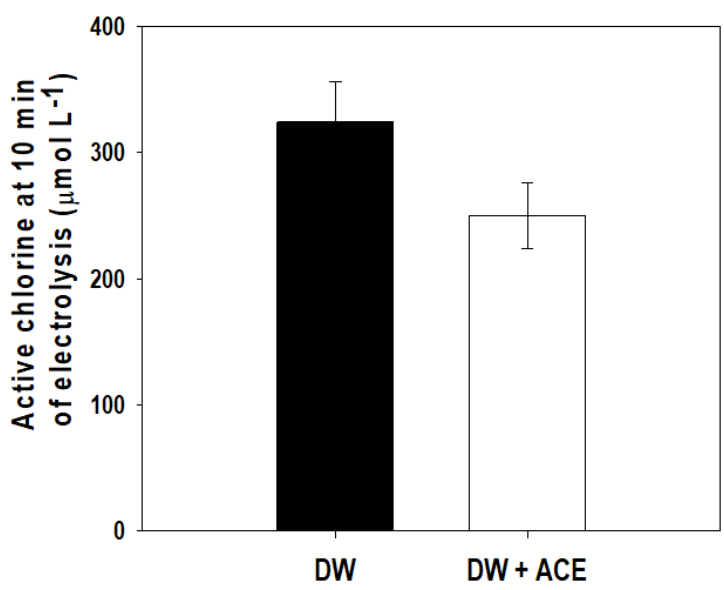

(b) Accumulation of oxidizing species in the absence (DW) and presence of acetaminophen (DW+ACE) using $\mathrm{NaCl}$ as supporting electrolyte (Experimental conditions: ACE: 40 umol i, NaCl: 0.05 mol i, i: $40 \mathrm{~mA}$, and $\mathrm{pH}: 6.01$

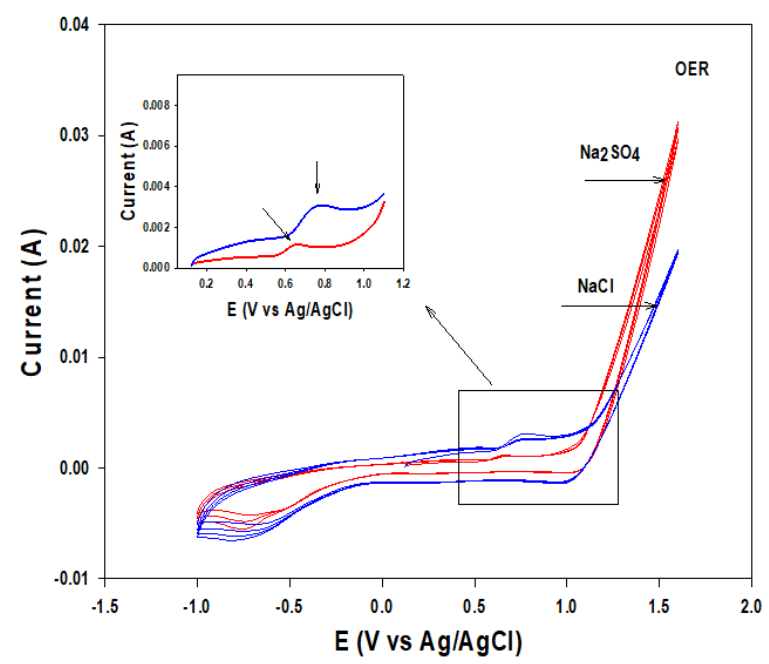

(c) Cyclic voltammetry for ACE in different supporting electrolytes (Conditions: $\mathrm{Na}_{2} \mathrm{SO}_{4}$ : $\mathrm{NaCl}: 0.05 \mathrm{~mol} L^{-1}$, and

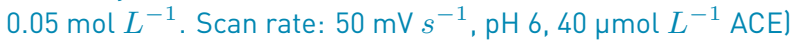

Figure 2 Electrochemical degradation of ACE

supporting the high susceptibility of such position to the chlorination.

NAPQI is a noxious substance, which can induce hepatic necrosis [40]. In turn, 1,4-benzoquinone is a well-known toxic product [48]. Additionally, products of ACE chlorination have potential toxicity per se due to their organochlorinated nature. Hence, the electrolysis time could be extended to promote the further oxidation of these initial compounds, or a post-treatment with UVC light of the resultant solutions may be applied to promote the formation of other powerful oxidizing agents (such as chlorine radical and hydroxyl radical, from the homolytic cleavage of the electrogenerated $\mathrm{HOCl}$ [47]). It is remarked the relevance of these kinds of experiments (treatment at long times or combination with UVC light). These should be performed in future studies to verify the elimination of such primary noxious products.

\subsection{Degradation of ACE in urine}

Urine is the main excretion route of ACE in humans after consumption [31]. Then, the feasibility of the electrochemical process to degrade ACE in simulated fresh urine was evaluated. Figure 5 a compares the degradation of ACE in urine and distilled water. As indicated in 
Table 2 Composition of synthetic fresh urine*

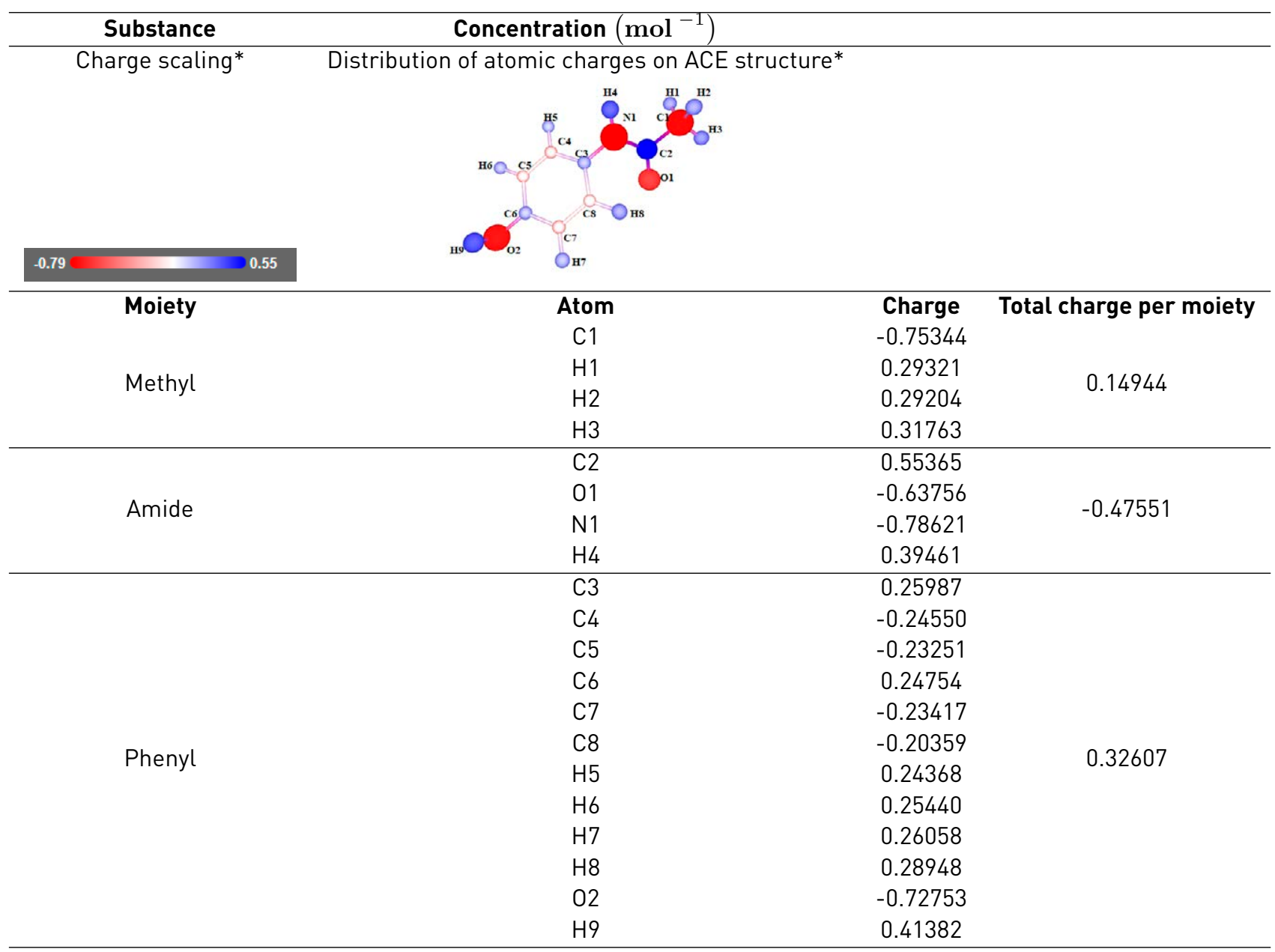

*Information obtained through a free online atomic charge calculator [33].

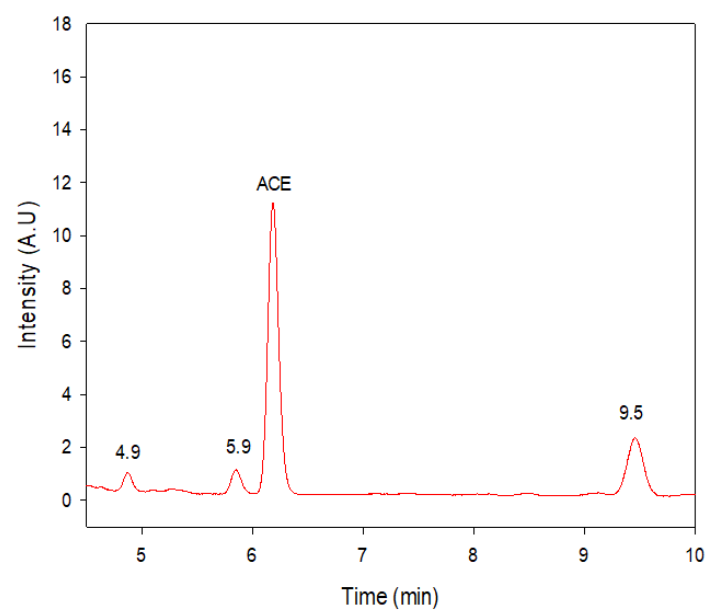

Figure 3 Chromatogram of ACE during the treatment by the electrochemical process
Table 3 Log P-values for ACE and some degradation products

\begin{tabular}{lc}
\hline Compound & Log P value* \\
\hline ACE & 0.68 \\
$1,4-$ benzoquinone & 0.56 \\
NAPQI & 0.63 \\
Mono-chlorinated acetaminophen & $>1.0^{* *}$ \\
Di-chlorinated acetaminophen & $>1.8^{* *}$ \\
\hline
\end{tabular}

Di-chlorinated acetaminophen $>1.8^{* *}$ 

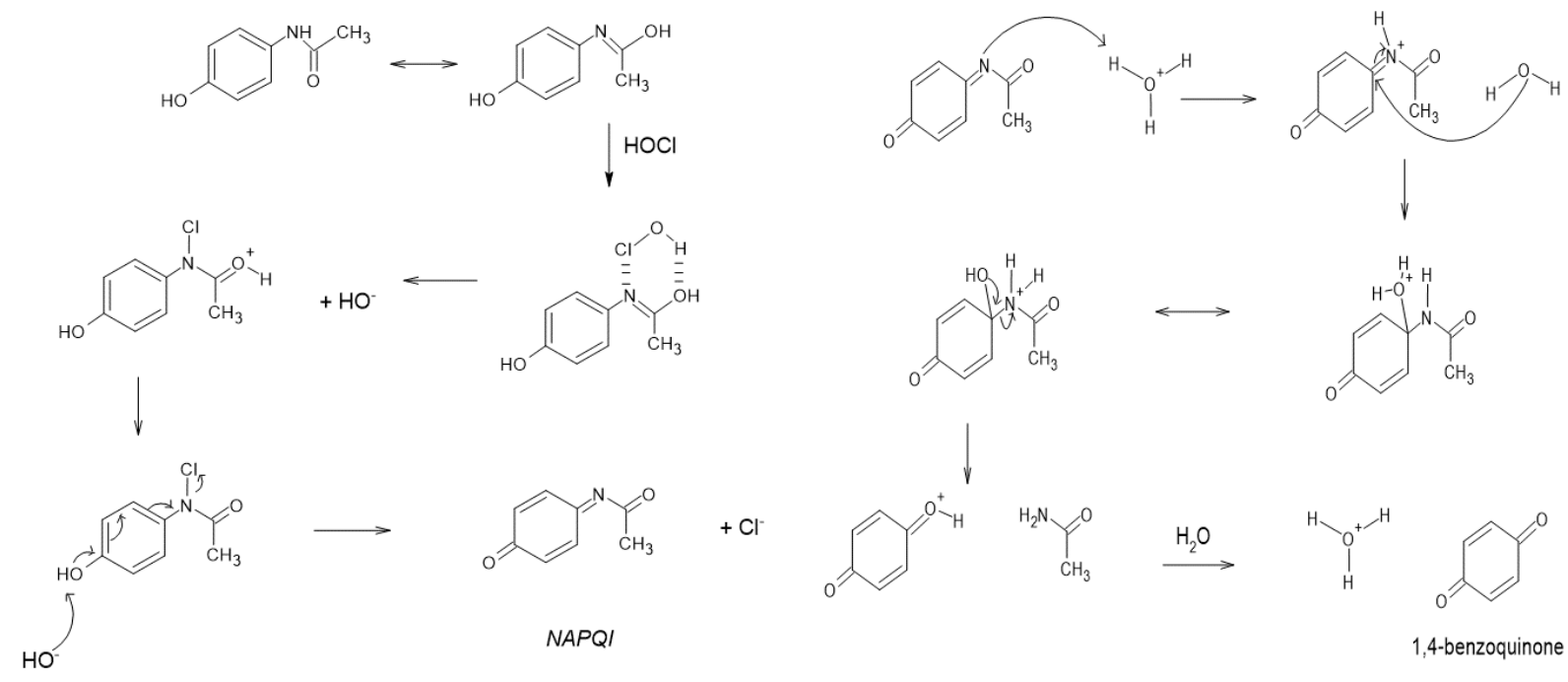

(a)

(b)<smiles>CC(=O)Nc1ccc(O)cc1</smiles><smiles>CC(=O)Nc1ccc(O)c(Cl)c1</smiles>

Monochlorinated product

(c)

Figure 4 * Log P-value was determined using the free online Molinspiration software [44] **Data obtained for calculations of chlorine atoms at different positions on the phenolic ring

Table 1, the fresh urine matrix contains a high amount of chloride ions $\left(0.107 \mathrm{~mol} L^{-1}\right)$; thus, it is expected a strong degrading action of the electrogenerated $\mathrm{HOCl}$ on ACE. However, the urine also has high concentrations of urea and ammonium/ammonia, and these substances are very reactive toward $\mathrm{HOCl}$ (Equations (10) and (11) $[30,35,49,50]$.

The reaction of urea and ammonium/ammonia with the RCS is supported by the lower accumulation of electrogenerated $\mathrm{HOCl}$ in the urine matrix compared with distilled water (both in the absence of ACE, Figure $5 b$ ). In the urine matrix, $21 \%$ of ACE was degraded after $60 \mathrm{~min}$ of electrolysis. This degradation of ACE is slower than that achieved in distilled water $(100 \%$ of removal at 10 min of treatment), as a consequence of the competition associated with the matrix components.

$\left(\mathrm{NH}_{2}\right)_{2} \mathrm{CO}+3 \mathrm{HOCl} \rightarrow \mathrm{CO}_{2}+\mathrm{N}_{2}+3 \mathrm{Cl}^{-}+2 \mathrm{H}_{2} \mathrm{O}+3 \mathrm{H}^{+}$
$\mathrm{NH}_{4}^{+} / \mathrm{NH}_{3}+\mathrm{HOCl} \rightarrow \mathrm{NH}_{2} \mathrm{Cl}+\mathrm{H}_{3} \mathrm{O}^{+} / \mathrm{NH}_{2} \mathrm{Cl}+\mathrm{H}_{2} \mathrm{O}$

\section{Conclusions}

The treatment of ACE in distilled water by electrogenerated RCS induced a fast elimination $110 \mathrm{~min}$ of treatment, under $40 \mathrm{~mA}$ of current, $0.05 \mathrm{~mol} L^{-1}$ of $\mathrm{NaCl}$, and using a DSA). The moieties most susceptible to attacks 


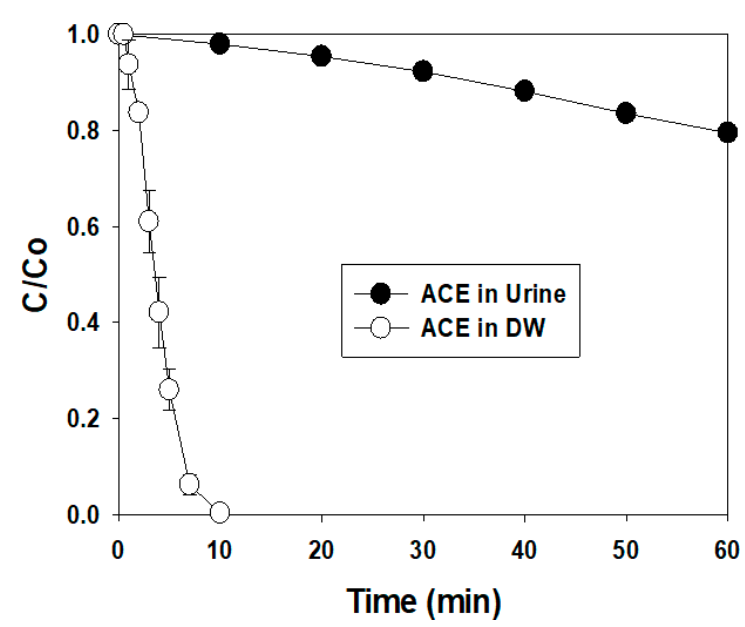

(a)

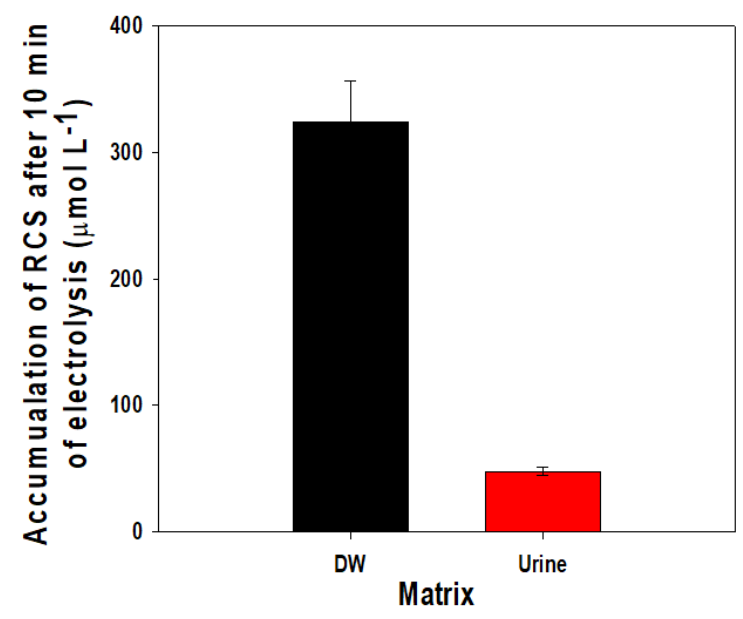

(b)

Figure 5 (a) ACE degradation in synthetic urine (Experimental conditions: ACE: $40 \mu \mathrm{mol} L-1, \mathrm{i}: 40 \mathrm{~mA}$ ). (b) Accumulation of $\mathrm{HOCl}$ in DW and Urine without ACE (Experimental conditions: $\mathrm{NaCl}: 0.05 \mathrm{~mol}$ L-1in DW, and i: $40 \mathrm{~mA}$ for both matrices)

by the RCS on ACE were the amide and aromatic ring. Indeed, the tested treatment could generate 1,4-benzoquinone, NAPQI, and chlorinated acetaminophen as primary degradation products. The process partially degraded the analgesic in urine due to competition between some components in the complex matrix and ACE by the electrogenerated RCS. Therefore, the present work showed that electrogenerated RCS using a $\mathrm{Ti} / \mathrm{IrO}_{2}$ anode is an alternative to treat aqueous media loaded with ACE.

\section{Declaration of competing interest}

We declare that we have no significant competing interests, including financial or non-financial, professional, or personal interests interfering with the full and objective presentation of the work described in this manuscript.

\section{Acknowledgments}

E.A. Serna-Galvis thanks MINCIENCIAS COLOMBIA for his Ph.D. scholarship during July 2015-June 2019 (Convocatoria 647/ 2014) and the financial support for his postdoctoral research (Convocatoria 848/ 2019).R.E Palma-Goyes thanks Banco de la República (FUNDACIÓN PARA LA PROMOCIÓN DE LA INVESTIGACIÓN Y LA TECNOLOGÍA), project No. 5.015, agreement 202204 for financial support.

\section{Funding}

This work was supported by MINCIENCIAS COLOMBIA (project No. 111585269594) and Universidad de Antioquia UdeA (Programa de Sostenibilidad).

\section{Author contributions}

Efraím A. Serna-Galvis: Investigation, Conceptualization, Methodology, Writing - Original Draft; Juan Esteban Ramírez: Investigation and Methodology; Ricardo E. Palma-Goyes: Conceptualization, Formal analysis, Writing - Review \& Editing; and Ricardo A. Torres-Palma: Conceptualization, Resources, Writing - Review \& Editing, and Funding acquisition.

\section{Data availability statement}

The authors confirm that the data supporting the findings of this study are available within the article.

\section{References}

[1] D. M. Whitacre, Reviews of Environmental Contamination and Toxicology, 202nd ed. New York, NY: Springer New York, 2010.

[2] A. Ziylan and N. H. Ince, "The occurrence and fate of anti-inflammatory and analgesic pharmaceuticals in sewage and fresh water: Treatability by conventional and non-conventional processes," Journal of Hazardous Material, vol. 187, no. 1-3, Mar. 15, 2011. [Online]. Available: https://doi.org/10.1016/j.jhazmat.2011.01. 057

[3] J. Rivera-Utrilla, M. Sánchez-Polo, M. A. Ferro-García, G. Prados-Joya, and R. Ocampo-Pérez, "Pharmaceuticals as emerging contaminants and their removal from water. a review," Chemosphere, vol. 93, no. 7, Oct. 2013. [Online]. Available: https://doi.org/10.1016/j.chemosphere.2013.07.059

[4] P. Verlicchi, M. A. Aukidy, and E. Zambello, "Occurrence of pharmaceutical compounds in urban wastewater: Removal, mass load and environmental risk after a secondary treatment-a review," Science of The Total Environment, vol. 429, Jul. 01, 2012. [Online]. Available: https://doi.org/10.1016/j.scitotenv.2012.04.028

[5] W. Sim, J. W. Lee, E. S. Lee, S. K. Shin, S. R. Hwang, and et. al, "Occurrence and distribution of pharmaceuticals in wastewater from households, livestock farms, hospitals and pharmaceutical manufactures," Chemosphere, vol. 82, no. 2, Jan. 2011. [Online]. Available: https://doi.org/10.1016/j.chemosphere.2010.10.026 
[6] J. G. M. Bessems and N. P. E. Vermeulen, "Paracetamol (acetaminophen)-induced toxicity: molecular and biochemical mechanisms, analogues and protective approaches," Critical Reviews in Toxicology, vol. 31, no. 1, Jan. 2001. [Online]. Available: https://doi.org/10.1080/20014091111677

[7] H. Jaeschke and M. L. Bajt, "Intracellular signaling mechanisms of acetaminophen-induced liver cell death," Toxicological Sciences, vol. 89, no. 1, Jan. 2006. [Online]. Available: https://doi.org/10.1093/ toxsci/kfi336

[8] B. Manu, S. Mahamood, H. Vittal, and S. Shrihari, "A novel catalytic route to degrade paracetamol by fenton process," International Journal of Research in Chemistry and Environment, vol. 1, no. 1, Jul. 01, 2011. [Online]. Available: t.ly/PuZK

[9] R. Andreozzi, V. Caprio, R. Marotta, and D. Vogna, "Paracetamol oxidation from aqueous solutions by means of ozonation and $\mathrm{h}_{2} \mathrm{O}_{2}$ /uv system," Water Research, vol. 37, no. 5, Mar. 2003. [Online]. Available: https://doi.org/10.1016/S0043-1354(02)00460-8

[10] M. Stucchi, M. G. Rigamonti, D. Carnevali, and D. C. Boffito, “A kinetic study on the degradation of acetaminophen and amoxicillin in water by ultrasound," ChemistrySelect, vol. 5, no. 47, Dec. 17, 2020. [Online]. Available: https://doi.org/10.1002/slct.202004147

[11] X. Zhang, F. Wu, X. Wu, P. Chen, and N. Deng, "Photodegradation of acetaminophen in tio 2 suspended solution," Journal of Hazardous Materials, vol. 157, no. 2-3, Sep. 2008. [Online]. Available: https: //doi.org/10.1016/j.jhazmat.2007.12.098

[12] J. J. Pignatello, E. Oliveros, and A. Mackay, "Advanced oxidation processes for organic contaminant destruction based on the fenton reaction and related chemistry," Critical Reviews in Environmental Science and Technology, vol. 36, no. 1, 2006. [Online]. Available: https://doi.org/10.1080/10643380500326564

[13] L. Yang, L. E. Yu, and M. B. Ray, "Degradation of paracetamol in aqueous solutions by tion photocatalysis," Water Research, vol. 42, no. 13, Jul. 2008. [Online]. Available: https://doi.org/10.1016/j. watres.2008.04.023

[14] I. Sirés and E. Brillas, "Remediation of water pollution caused by pharmaceutical residues based on electrochemical separation and degradation technologies: A review," Environment International, vol. 40, Apr. 2012. [Online]. Available: https://doi.org/10.1016/j. envint.2011.07.012

[15] M. Panizza and G. Cerisol, "Direct and mediated anodic oxidation of organic pollutants," Chem. Rev., vol. 109, no. 12, Aug. 06, 2009. [Online]. Available: https://doi.org/10.1021/cr9001319

[16] F. Zaviska, P. Drogui, J. Blais, G. Mercier, and S. D. L. R. d'Auzay, "Electrochemical oxidation of chlortetracycline using ti/iro 2 and ti/pbo 2 anode electrodes: Application of experimental design methodology," Journal of Environmental Engineering, vol. 139, no. 6, Jun. 2013. [Online]. Available: https://doi.org/10.1061/(ASCE)EE. 1943-7870.0000686

[17] A. L. Giraldo, E. D. Erazo-Erazo, O. A. Flórez-Acosta, E. A. Serna-Galvis, and R. A. Torres-Palma, "Degradation of the antibiotic oxacillin in water by anodic oxidation with ti/iro 2 anodes: Evaluation of degradation routes, organic by-products and effects of water matrix components," Chemical Engineering Journal, vol. 279, Nov. 01, 2015. [Online]. Available: https://doi.org/10.1016/j.cej.2015.04.140

[18] F. L. Guzmán-Duque, R. E. Palma-Goyes, I. González, G. Peñuela, and R. A. Torres-Palma, "Relationship between anode material, supporting electrolyte and current density during electrochemical degradation of organic compounds in water," Journal of Hazardous Materials, vol. 278, Aug. 15, 2014. [Online]. Available: https: //doi.org/10.1016/j.jhazmat.2014.05.076

[19] I. Sirés, E. Brillas, M. A. Oturan, M. A. Rodrigo, and M. Panizza, "Electrochemical advanced oxidation processes: today and tomorrow. a review," Environmental Science and Pollution Research, vol. 21, Apr. 02, 2014. [Online]. Available: https://doi.org/10.1016/j.jhazmat.2014.05.076

[20] F. C. Moreira, R. A. R. Boaventura, E. Brillas, and V. J. P. Vilar, "Electrochemical advanced oxidation processes: A review on their application to synthetic and real wastewaters," Applied Catalysis B: Environmental, vol. 202, Mar. 2017. [Online]. Available: https://doi.org/10.1016/j.apcatb.2016.08.037
[21] R. E. Palma-Goyes, E. A. Serna-Galvis, J. E. Ramirez, and R. A Torres-Palma, "Electrochemical degradation of naproxen (npx) and diclofenac ( $\mathrm{dfc})$ through active chlorine species ( $\mathrm{Cl}_{2}$-active): Considerations on structural aspects and degradation in urine," ECS Transactions, vol. 100, no. 1, 2021. [Online]. Available: https://doi.org/10.1149/10001.0055ecst

[22] D. C. de Moura, C. K. C. de Araújo, C. L. P. S. Zanta, R. Salazar, and C. A. Martínez-Huitle, "Active chlorine species electrogenerated on ti/ru0.3ti0.7o2 surface: Electrochemical behavior, concentration determination and their application," Journal of Electroanalytical Chemistry, vol. 731, 2014. [Online]. Available: https://doi.org/10. 1016/j.jelechem.2014.08.008

[23] M. Deborde and U. von Gunten, "Reactions of chlorine with inorganic and organic compounds during water treatment-kinetics and mechanisms: A critical review," Water Research, vol. 42, no. 1-2, Jan. 2008. [Online]. Available: https://doi.org/10.1016/j.watres. 2007.07.025

[24] M. Luna-Trujillo, R. E. Palma-Goyes, J. Vazquez-Arenas, and A. Manzo-Robledo, "Formation of active chlorine species involving the higher oxide $\mathrm{mo}_{\mathrm{x}+1}$ on active ti/ruo $\mathrm{H}_{2}-\mathrm{iro}_{2}$ anodes: A dems analysis," Journal of Electroanalytical Chemistry, vol. 878, Dec. 01, 2020. [Online]. Available: https://doi.org/10.1016/j.jelechem.2020. 114661

[25] R. E. Palma-Goyes, J. Vazquez-Arenas, C. Ostos, A. Manzo-Robledo, I. Romero-Ibarra, and et. al, "In search of the active chlorine species on ti/zro $2-\mathrm{ruO}_{2}-\mathrm{Sb}_{2} \mathrm{O}_{3}$ anodes using dems and xps," Electrochimica Acta, vol. 275, Jun. 2018. [Online]. Available: https: //doi.org/10.1016/j.electacta.2018.04.114

[26] R. E. Palma-Goyes, J. Macías, I. González, and R. A. Torres-Palma, "Tratamiento de aguas residuales provenientes de la industria textil mediante oxidación electroquímica," Rev. Colomb. Mater., no. 4, Apr. 2013. [Online]. Available: https://revistas.udea.edu.co/index.php/ materiales/article/view/15085/13162

[27] A. L. G. Aguirre, E. D. E. Erazo, O. A. F. Acosta, E. A. S. Galvis, and R. A. Torres-Palma, "Tratamiento electroquímico de aguas que contienen antibióticos $\beta$-lactámicos," Ciencia en Desarrollo, vol. 7, no. 1, Jan-Jun. 2016. [Online]. Available: https://doi.org/10.19053/01217488.4227

[28] M. L. Zavala and E. E. Estrada, "Degradation of acetaminophen and its transformation products in aqueous solutions by using an electrochemical oxidation cell with stainless steel electrodes," Water, vol. 8, no. 9, 2016. [Online]. Available: https://doi.org/10. 3390/w8090383

[29] M. A. López, D. A. Vega, J. M. Álvarez, O. F. Castillo, and R. A. Cantú, "Electrochemical oxidation of acetaminophen and its transformation products in surface water: effect of ph and current density," Heliyon, vol. 6, no. 2, Feb. 08, 2020. [Online]. Available: https://doi.org/10.1016/j.heliyon.2020.e03394

[30] V. Amstutz, A. Katsaounis, A. Kapalka, C. Comninellis, and K. M. Udert, "Effects of carbonate on the electrolytic removal of ammonia and urea from urine with thermally prepared iro, electrodes," Journal of Applied Electrochemistry, vol. 42, 2012. [Online]. Available: https://doi.org/10.1007/s10800-012-0444-y

[31] M. C. Bhowmik, M. Misbahuddin, and H. A. Bhuiyan, "Estimation of paracetamol in urine to assess the diurnal variation," Bangabandhu Sheikh Mujib Medical University Journal, vol. 11, no. 2, May. 30, 2018. [Online]. Available: https://doi.org/10.3329/bsmmuj.v11i2.36780

[32] A. E. Yañez-Rios, J. E. Carrera-Crespo, R. M. Luna-Sanchez, R. E. Palma-Goyes, and J. Vazquez-Arenas, "The influence of ph and current density on an uv254 photo-assisted electrochemical process generating active chlorine and radicals for efficient and rapid ciprofloxacin mineralization compared to individual techniques," Journal of Environmental Chemical Engineering, vol. 8, no. 5, Oct. 2020. [Online]. Available: https://doi.org/10.1016/j.jece.2020.104357

[33] Atomic Charge Calculator, Web Chemistry, Czech Republic. [Online]. Available: https://webchem.ncbr.muni.cz/Platform/ ChargeCalculator

[34] E. A. Serna-Galvis, S. D. Jojoa-Sierra, K. E. Berrio-Perlaza, F. Ferraro, and R. A. Torres-Palma, "Structure-reactivity relationship in the degradation of three representative 
fluoroquinolone antibiotics in water by electrogenerated active chlorine," Chemical Engineering Journal, vol. 315, no. 1, May. 01, 2017. [Online]. Available: https://doi.org/10.1016/j.cej.2017.01.062

[35] L. A. Perea, R. E. Palma-Goyes, J. Vásquez-arenas, I. Romero-lbarra, C. Ostos, and et al., "Efficient cephalexin degradation using active chlorine produced on ruthenium and iridium oxide anodes: Role of bath composition, analysis of degradation pathways and degradation extent," Science of The Total Environment, vol. 648, Jan. 15, 2019. [Online]. Available: https://doi.org/10.1016/j.scitotenv.2018.08.148

[36] C. Comninellis and G. Chen, Electrochemistry for the Environment, 1st ed. New York, NY: Springer, 2010.

[37] A. Kraft, M. Stadelmann, M. Blaschke, D. Kreysig, B. Sandt, and et al., "Electrochemical water disinfection part i: Hypochlorite production from very dilute chloride solutions," Journal of Applied Electrochemistry, vol. 29, 1999. [Online]. Available: https://doi.org/ 10.1023/A:1003650220511

[38] L. R. Czarnetzki and L. J. J. Janssen, "Formation of hypochlorite, chlorate and oxygen during nacl electrolysis from alkaline solutions at an $\mathrm{ruO}_{2} / \mathrm{tio}_{2}$ anode," Journal of Applied Electrochemistry, vol. 22, 1992. [Online]. Available: https://doi.org/10.1007/BF01092683

[39] K. E. Pinkston and D. L. Sedlak, "Transformation of aromatic ether- and amine-containing pharmaceuticals during chlorine disinfection," Environ. Sci. Technol., vol. 38, no. 14, 2004. [Online]. Available: https://doi.org/10.1021/es035368l

[40] M. Bedner and W. A. MacCrehan, "Transformation of acetaminophen by chlorination produces the toxicants 1,4-benzoquinone and $\mathrm{N}$-acetyl-p-benzoquinone iminen," Environ. Sci. Technol., vol. 40, no. 2, 2006. [Online]. Available: https://doi.org/10.1021/es0509073

[41] I. Xagoraraki, R. Hullman, W. Song, H. Li, and T. Voice, "Effect of ph on degradation of acetaminophen and production of 1,4-benzoquinone in water chlorination," Journal of Water Supply: Research and Technology-Aqua, vol. 57, no. 6, 2008. [Online]. Available: https: //doi.org/10.2166/aqua.2008.095

[42] J. Lu, Q. Huang, and L. Mao, "Removal of acetaminophen using enzyme-mediated oxidative coupling processes: I. reaction rates and pathways," Environ. Sci. Technol., vol. 43, no. 18, Aug. 13, 2009. [Online]. Available: https://doi.org/10.1021/es9002422

[43] F. Cao, M. Zhang, S. Yuan, J. Fenga, Q. Wang, and et al., "Transformation of acetaminophen during water chlorination treatment: kinetics and transformation products identification," Environ Sci Pollut Res, vol. 23, 2016. [Online]. Available: https://doi.org/10.1007/s11356-016-6341-x

[44] Calculation of Molecular Properties and Bioactivity Score, Molinspiration Cheminformatics. [Online]. Available: https: //www.molinspiration.com/cgi-bin/properties

[45] G. Barassi and T. Borrmann, "N-chlorination and orton rearrangement of aromatic polyamides, revisited," J. Memb. Sci. Technol., vol. 2, no. 2, 2012. [Online]. Available: https: //doi.org/10.4172/2155-9589.1000115

[46] D. C. Dahlin, G. T. Miwa, A. Y. H. Lu, and S. D. Nelson, "N-acetyl-p-benzoquinone imine: a cytochrome $\mathrm{p}$-450-mediated oxidation product of acetaminophen," PNAS, vol. 81, no. 5, Mar. 01 , 1984. [Online]. Available: https://doi.org/10.1073/pnas.81.5.1327

[47] Y. H. Dao, H. N. Tran, T. T. Tran-Lam, T. Q. Pham, and G. T. Le, "Degradation of paracetamol by an uv/chlorine advanced oxidation process: Influencing factors, factorial design, and intermediates identification," Int. J. Environ. Res. Public Health, vol. 15, no. 12, 2018. [Online]. Available: https://doi.org/10.3390/ijerph15122637

[48] J. T. Trevors and J. Basaraba, "Toxicity of benzoquinone and hydroquinone in short-term bacterial bioassays," Bull. Environ. Contam. Toxicol., vol. 25, 1980. [Online]. Available: https://doi.org/ 10.1007/BF01985590

[49] E. R. Blatchley and M. Cheng, "Reaction mechanism for chlorination of urea," Environ. Sci. Technol., vol. 44, no. 22, 2010. [Online]. Available: https://doi.org/10.1021/es102423u

[50] M. S. Rayson, M. Altarawneh, J. C. Mackie, E. M. Kennedy, and B. Z. Dlugogorski, "Theoretical study of the ammonia-hypochlorous acid reaction mechanism," J. Phys. Chem. A, vol. 114, no. 7, 2010. [Online]. Available: https://doi.org/10.1021/jp9088657 